\title{
"Disk-Television": Some Recurring Copyright Problems in the Reproduction and Performance of Motion Pictures $\dagger$
}

The art of recording and reproducing pictures in motion ${ }^{1}$ has been expanded by a revolutionary new device which is now in an advanced stage of development. The Columbia Broadcasting System has developed "a metal disk that reproduces motion pictures through a television set in much the same manner as a long-playing record reproduces music through a high fidelity phonograph ...."2 The social and economic implications of disk-television, a major advance over magnetic tape, are almost limitless. ${ }^{3}$ Viewers, in the privacy of their homes,

† Boardman Lloyd, J.D. 1967, The University of Chicago Law School. This essay was awarded First Prize in the 1966 Nathan Burkan Memorial Competition at the University of Chicago Law School, and Fourth Prize in the National Competition. It is published through the courtesy of the American Society of Composers, Authors and Publishers.-Ed.

1 A useful definition of motion pictures given in the proposed revision of the Copyright Act presently before Congress: "'Motion pictures' are audiovisual works consisting of a series of related images which, when shown in succession, impart an impression of motion, together with accompanying sounds, if any." "Audiovisual works" are defined as "works that consist of a series of related images which are intrinsically intended to be shown by the use of machines or devices such as projectors, viewers, or electronic equipment, together with accompanying sounds, if any, regardless of the nature of the material objects, such as films or tapes, in which the works are embodied." H.R. 2512, 90th Cong., Ist Sess. § 101 (1967).

2 N.Y. Times, Feb. 28, 1966, p. 1, col. 6. See also Wall Street Journal, March 1, 1966, p. 31, col. 3 .

3 Disk-television avoids the major problems which have apparently blocked, or at least slowed down, the successful development and marketing of subscription television. See Comment, Aspects of Pay Television: Regulation, Constitutional Law, Antitrust, 53 CarIF. L. REv. 1378 (1965); N.Y. Times, Feb. 28, 1966, p. 34, col. 6. The fact that subscription television has lagged behind commercial broadcasting is "due in large part to technical and economic considerations." Comment, supra, 53 GALIF. L. REV. at I381. Subscription television is further limited by the regulatory powers of the Federal Communications Commission. Fischer's Blend Station, Inc. v. State Tax Comm'n, 297 U.S. 650, 655 (1936). See also Federal Radio Comm'n v. Nelson Bros. Bond \& Mortgage Co., 289 U.S. 266, 279 (1933); Allen B. Dumont Laboratories v. Carroll, 184 F.2d 153, 154-55 (3d Cir. 1950), cert. denied, 340 U.S. 929 (1951). It has been suggested that closed circuit pay television will also come under the jurisdiction of the FCC. See Comment, supra, 53 CALrF. L. REv. at 1386-91. Because there is no radio broadcast involved in the performance of disk-television, it does not share with subscription television the technical, political, and economic problems of radio wave transmission. Furthermore, unlike subscription television, the viewer of disk-television may lease or buy a disk and watch it when he chooses.

Advocates of subscription television have pointed out that "free" television must, because of the demands of its sponsor-advertiser, compromise the subject matter of its programs in order to attract the largest possible number of viewers. See Kalven \& Rosenfield, Minow Should Watch Fis Step in the Wasteland, Fortune, Oct., 1962, pp. 116, 148. 
will have a variety in choice of motion pictures similar to that now enjoyed in the selection of long-playing music records. The television disks are of simple construction and could be sold or rented by supermarkets or other stores. ${ }^{4}$

Although the development of disk-television promises significant advantages to the average home television viewer, it simultaneously crystallizes several difficult copyright problems which, for some time, have plagued the motion picture industry. Under what circumstances will the unauthorized manufacture ${ }^{5}$ or the unauthorized performance ${ }^{6}$ of a motion picture constitute an infringement of the rights of the holder of the movie's copyright? A more theoretical question, which will also be considered here, is whether the unauthorized manufacture or performance of a motion picture should ever constitute a copyright infringement, ${ }^{\top}$ and if so, under what circumstances?

\section{The Rights of a Motion Picture Copyright Owner to the Reproduction and Performance of His Work}

In White-Smith Music Publishing Co. v. Apollo Co., ${ }^{8}$ the proprietor of two duly copyrighted musical compositions sued to restrain the defendant manufacturer from making and selling perforated music rolls (pianola rolls) which, when used with certain musical instruments also manufactured by the defendant, reproduced "in sound the melody recorded in the two pieces of music copyrighted by the appellant [plaintiff]." The question before the Supreme Court was whether the perforated music rolls were "copies"10 of the appellant's musical com-

In short, "free" television must appeal to the tastes of the majority. Subscription television, on the other hand, would, as in the case of the book market, be able to diversify the subject matter of its programs and thus reach the demand created by specific minority interests which are not satisfied by "free" television. Thus, "if the problem is that the current T.V. market does not work like the book market, the solution should be to make it possible for T.V. to function more like a book market." Id. at 148. In this respect, disktelevision, because of the technical simplicity in the performance of the disks, and the limitless area in which the disks can be marketed, provides a closer analogy to the book market than does subscription television, and thus appears to be a more desirable system.

4 N.Y. Times, Feb. 28, 1966, p. 34, col. 7.

5 "Unauthorized manufacture" means the manufacture of a copyrighted work without the right to such manufacture derived either directly from the copyright law, or from a license granted by the owner of the copyrighted work.

6 "Unauthorized performance" means the performance of a copyrighted work without the right to such performance derived either directly from the copyright law, or from a license granted by the owner of the copyrighted work.

$7 \mathrm{~A}$ related issue is whether books and phonograph records should be treated the same as motion pictures, or whether it is possible to make reasonable distinctions between these different mediums. See note 68 infra.

8209 U.S. 1 (1907).

o Id. at 9.

10 Section $1(a)$ of the Copyright Act states that "any person entitled thereto, upon 
positions; that is, whether the making of the rolls infringed the exclusive right to "copy" the musical compositions secured to the composer or proprietor under the existing statutes. ${ }^{11}$ The appellant contended that although the perforated notation on the piano rolls was a different type of notation than that used on sheet music, the music roll was "none the less a 'musical composition,' none the less a perfect record, and none the less a 'writing." "12 However, the Court held that the perforated music rolls were not "copies" of the musical compositions under section 1(a), nor, more specifically, of the sheet music on which the musical compositions were written. The Court stated that the "musical tones [recorded. on the music rolls] are not a copy which appeals to the eye. . . Even those skilled in the making of these rolls are unable to read them as musical compositions, as those in staff notation are read by the performer." 13 The music rolls "are not intended to be read as an ordinary piece of sheet music."14 Finally, the perforated music rolls were essentially "parts of a machine" and therefore distinguishable from a "copy" within the meaning of the Copyright Act.15

It is not clear, under the doctrine of the Apollo case, whether a disk would constitute a "copy" of a motion picture film from which it was made. An arguable distinction can be made between the "music rollsheet music," and the "disk-motion picture film" groupings. Sheet music can be read from and is used for that purpose by musicians, and, in Apollo, this was held not to be true of music rolls made from the sheet music.

The "can't read it" distinction used in the Apollo case is less applicable to the latter grouping. Neither disks nor motion picture films are "read" in the way that sheet music is read by musicians. Further, disks and motion picture films are similar to the extent that both are merely "part of a machine." That a disk might be held a copy of the motion picture film from which it was made gains support from Aeolian Co. v. Royal Music Roll Co. ${ }^{16}$ In that case, an action was brought to restrain the Royal Music Company from copying and duplicating perforated music rolls manufactured by the complainant. In granting relief to the complainant the Court held that the making of

complying with the provisions of this title, shall have the exclusive right: (a) to print, reprint, publish, copy, and vend copyrighted work ...." 17 U.S.C. § 1(a) (1964).

11 For further discussion on this issue, see Meagher, Copyright Problems Presented by a New Art, 30 N.Y.U. L. Rev. 1081, 1091 (1955).

12 White-Smith Music Publishing Co. v. Apollo Co., 209 U.S. 1, 4 (1907).

13 Id. at $17-18$.

14 Ibid.

15 Ibid.

16196 Fed. 926 (W.D. N.Y. 1912). 
music rolls from previously made music rolls was an infringement of section I(a) of the Copyright Act. The Court's opinion emphasized that Congress intended to protect copyright owners in their right to their productions, and that the respondent could not "avail himself of the skill and labor of the original manufacturer of the perforated roll or record by copying or duplicating the same ..."17 The reasoning of the Apollo and Aeolian cases arguably suggests that although a disk has a different form from that of a motion picture film, the disk is part of a machine and, essentially, a copy or duplication of the skill and labor incorporated in the motion picture film, and therefore a "copy" within the meaning of the Copyright Act.

However, other language of the Apollo decision suggests that a disk would not constitute a "copy" of a motion picture film under section 1(a). The Court in Apollo adopted a narrow definition of "copy" requiring that the copying be apparent to the eye. The majority cited with approval the definition of copy proposed in the early English case of West $v$. Francis. ${ }^{18}$ In that case, the plaintiff was the proprietor of seven prints from which the defendant made five hundred copies. The English court, while holding the defendant liable to an action by the proprietor of the original prints, stated that "a copy is that which comes so close to the original as to give to every person seeing it the idea created by the original."19 Under such a limited definition it would probably be held that a disk is not a copy of a motion picture film since the content of the motion picture can not be "seen" by merely looking at the disk. The Court also stated that "the [copyright] statute has not provided for the protection of the intellectual conception apart from the thing produced . . . "; ${ }^{20}$ and although it may be true in the Apollo case that the use of the perforated rolls enabled the respondent manufacturers to "enjoy the use of musical compositions for which they pay no value ...," such considerations "properly address themselves to the legislative and not to the judicial branch of the Government."21 Accordingly, it is arguable that section 1 (a) protects the proprietor of a motion picture film only to the extent of the "thing"-i.e., the motion picture film-itself, and that, therefore, the manufacture of a disk, though made from a motion picture film would not appear to be an infringement under section $1(\mathrm{a})$.

Although the disk is not a "copy" of a motion picture film or videotape within the present meaning of the Copyright Act, the unauthorized

17 Id. at 927.

185 B \& Ald. 737 (1822).

19 Id. at 743 .

20 White-Smith Music Publishing Co. v. Apollo Co., 209 U.S. 1, 17 (1907).

21 Id. at 18. 
performance of a disk on a television screen might be considered an infringement. Rights to the performance of motion pictures were given limited protection in the district court case of Tiffany Productions, Inc. v. Dewing. ${ }^{22}$ In that case it was assumed, but not held, that the performance of motion pictures was neither a "publication" nor a "copy" within the meaning of section 1(a). The court held, however, that the unauthorized exhibition of motion picture "photoplays" infringed the exclusive rights secured for "dramatic works" under section $I(d),{ }^{23}$ which protects the right to exhibit, perform, represent, produce or reproduce it in any manner or by any method whatsoever. ${ }^{24}$ The court did not extend its holding to "motion-pictures other than photoplays" 25 since they could not be considered "dramatic works." The holding is further limited by the conditions of section 1 (d) which gives copyright protection to the performance of a "dramatic work" only when such performance is "public."26

The subsequent district court decision of Metro-Goldwyn-Mayer Distributing Corp. v. Bijou Theater Co. ${ }^{27}$ significantly expanded the Tiffany holding. Although the court did not unhesitatingly accept the conclusion that motion picture photoplay films are dramatic works and thereby protected under section $1(\mathrm{~d})$, it did state that "motionpicture photoplays are either dramatic works entitled to protection under subdivision (d) of section 1 [performance of a dramatic work] ... whose unauthorized performance is an infringement of the performing rights given to dramatic works, or they are nondramatic works entitled to protection under subdivision (b) [dramatization of a nondramatic work]." ${ }^{28}$ Under either section there would be no protection for a motion picture which did not meet the minimum plot requirements of a "dramatic"composition. ${ }^{29}$

2250 F.2d 911 (D. Md. 1931).

23 Section 1(d) of the Copyright Act provides that "any person entitled thereto, upon complying with the provisions of this title, shall have the exclusive right .... (d) To perform or represent the copyrighted work publicly if it be a drama . . ." I7 U.S.C. § 1(d) (1964).

24 "[T] he court in thus bringing a motion picture photoplay within the 'dramatic works' to which section 1(d) applies, found no contrary significance in the existence of separate classifications for dramatic or dramatico-musical compositions and for motionpicture photoplays in section 5." Meagher, supra note 11, at 1095.

2517 U.S.C. $\S 5(\mathrm{~m})$ (1964). This section provides for the registration of motion pictures other than photoplays. See NIMMER, CopyriGHT § 25.1 (1966).

26 See note 23 supra. See also NimmER, COPYright § 107.2 (1966).

273 F. Supp. 66 (D. Mass. 1933).

28 Id. at 73. Section I(b) of the Copyright Act states that "any person entitled thereto, upon complying with the provisions of this title, shall have the exclusive right ... (b) to ... make any version thereof, if it be a literary work; to characterize it if it be a non dramatic work ...." 17 U.S.C. § I(b) (1964).

29 For varying definitions of "dramatic work," see Seltzer v. Sunbrock, 22 F. Supp. 621 
According to the Tiffany and Bijou cases, the exhibition rights of a motion picture copyright owner are strictly limited to motion picture photoplays. However, these rights were given unrestricted scope by the unprecedented decision of the Second Circuit in Patterson v. Century Productions, Inc. ${ }^{30}$ in which the concept of "copy" under section 1(a) was stretched to include the projection of a motion picture onto a screen. In that case, the complainant, Patterson, had filmed 15,000 feet of wild animal scenes, 6,000 feet of which he selected and arranged into a motion picture, and had copyrighted under section $5(\mathrm{~m})$ of the Copyright Act as a motion picture "other than a photoplay." In some unauthorized way (not indicated in the opinion), the defendant film company came into possesion of the positive copies which the complainant had made from his motion picture, and was thereby able to incorporate 1,000 to 1,500 feet of the complainant's work into a motion picture produced by the defendant which was later exhibited in public and for profit. The court said that:

[W] hen the film was shown the defendants who did that made an enlarged copy of the picture. It was to be sure temporary but still a copy while it lasted. I suppose a painting reproduced in colors that quickly faded to leave the canvas blank would, when the reproduction was complete, be a copy regardless of its life as such. ${ }^{31}$

By thus giving protection under section 1 (a) rather than under section $1(d)$, or even $1(b)$, the court effectively bypassed the "public performance" and "dramatic" limitations imposed by the latter sections. Under this expansive construction of section $1(a)$, any unauthorized performance, public or private, for profit or not for profit, of any copyrighted motion picture would appear to be an infringement.

The Patterson decision was, however, narrowly interpreted by the recent district court case of Mura $v$. Columbia Broadcasting System, Inc. ${ }^{32}$ The action in that case was brought by the owner of copyrights covering certain hand puppets which were allegedly displayed by the defendant, Columbia Broadcasting System, on its "Captain Kangaroo Show." The court held that the evanescent reproduction of a hand puppet on a television screen or on a projected kinescope recording was "so different in nature from the copyrighted hand puppet"33 that

(S.D. Cal. 1938); Daly v. Palmer, 6 Fed. Cas. Il32 (No. 3552) (S.D.N.Y. 1868); O'Neill v. General Film Co., 152 N.Y. Supp. 599 (Sup. Ct. 1915), modified, 171 App. Div. 854, 157 N.Y. Supp. 1028 (1916).

3093 F. 2d 489 (2d Cir. 1937).

31 Id. at 493 .

32147 U.S.P.Q. 38 (S.D.N.Y. 1965).

33 Id. at 40. 
there was no "copying" within the meaning of section $\mathrm{I}$ (a). In so holding, the decision impliedly distinguished the Patterson case on its facts. The court cited Patterson for the proposition that "it is obvious that a copyright of a work of art may be infringed by reproduction of the object itself," 34 thereby implying that in Patterson the image on the movie screen was a copy because the image was an actual reproduction of the images in each frame of the copyrighted motion picture film, while holding that "the puppets were not reproduced" by the temporary, evanescent image of the puppets on a television screen. ${ }^{35}$

Although the holding of the Mura case carries little precedential weight, the opinion does reveal the confusion in the law as to the meaning of "copy" under section 1(a). With respect to disk-television, it might be argued, consistent with the logic of the Mura case, that the performance of a disk on a television screen would not be a "copy" of a disk, or a videotape recording, whereas under the Patterson doctrine a performance, in the case where the disk was made from a motion picture film, might be found to be a "copy" of that motion picture. Such reasoning might also suggest that the exhibition of a videotape recording on a television screen would not be a "copy" of the videotape under section 1(a) because the images on the screen would not actually reproduce the videotape, as it would the individual frames in a motion picture film.

The fine distinctions suggested by the case law between the different types of motion picture devices, e.g., motion picture films and videotape, seem to be less a result of the policy underlying copyright protection than of outdated concepts which did not anticipate the extensive development of motion pictures films, television, and disk-television. The question then arises as to whether these distinctions should exist. For the purposes of the copyright law, no logical distinction can be made between the different types of motion picture devices. All are simply mechanical methods of creating pictures in motion. Where, for example, a disk is produced by using a motion picture film, the disk should be considered a copy of the original motion picture. This would provide the motion picture copyright owner with a source of control over the production of his work through leasing or contract arrangements, and with a remedy against unauthorized reproduction of his work under section 1(a). Furthermore, in order to avoid the spurious distinctions which classify the image on a screen a "copy" of one device but not of another, the law should either expand its definition of "copy" under section 1 (a) to include the performance of motion pictures, or 
include in the Copyright Act explicit recognition of the exclusive right of a motion picture copyright owner to the performance of his motion picture.

The proposition that the owner of a motion picture copyright should have an exclusive right to the performance of his motion picture has, however, come under some attack. ${ }^{36}$ The debate centers mainly on whether the owner of a motion picture copyright should have the exclusive right to all exhibitions without qualification, or whether such a right should be limited to public performances or to performances made for profit.

\section{The "For Profit" Limitation"}

Under the Copyright Act, an unauthorized public performance of a "musical composition" or of a "nondramatic literary work" will infringe the rights of the owner only if such performance is made for profit. ${ }^{38}$ In contrast, the "unauthorized public performance of a dramatic work infringes regardless of whether or not it is for profit." 39 The "for profit" limitation first appeared in the copyright reform of 1909.40 The final report on the bill ${ }^{41}$ gave the following justification for not imposing a profit limitation on the performance of dramatic works:

It is usual for the author of a dramatic work to refrain from reproducing copies of the work for sale. He does not usually publish his work in the ordinary acceptance of the term, and hence in such cases never receives any royalties on copies sold. . . . If an author desires to keep his dramatic work in unpublished form and give public representations thereof only, this right should be fully secured to him by law. We have endeavored to so frame this paragraph as to amply secure him these rights. ${ }^{42}$

An extension of this argument focuses more directly on the protection

36 See generally Varmer for the Subcomm. on Patents, Trademarks, and Copyrights, Senate Comm. on the Judiciary, 86th Cong., 2d Sess., Study No. 16: Limitations on Performing Rights 81, 125-35 (Comm. Print 1958).

37 'In order to constitute a performance 'for profit' it is not necessary that a direct payment be made, as an admission charge or otherwise, for the performance. A performance will be 'for profit' if it occurs with an expectation by the person causing such a performance of direct or indirect commercial advantage or gain to be derived therefrom." Nmmer, Copyright § 107.32, at 403 (1966).

3817 U.S.C. $\$ \$ 1$ (c), (e) (1964).

3917 U.S.C. § 1(d) (1964).

40 VARMER, op. cit. supra note 36 , at 81-82.

41 H.R. REP. No. 222, 60th Cong., 2d Sess. (1909).

42 Id. at 4. 
of the copyright owner's right to the commercial exploitation of his work. ${ }^{43}$ "If a dramatic work is performed, even on a nonprofit basis, those who view such performance are not likely thereafter to attend a performance for profit of the same work." 44 The theory is that any performance of a dramatic work "in some degree diminishes the potential revenue to be obtained from performances for profit." 45 Such considerations support the argument that the rights to the performance of motion pictures should not be limited to performances for profit. The performance of a motion picture, like that of a dramatic work, is normally seen only once. In fact, it would seem that the argument against a "for profit" limitation is more applicable to motion pictures than to dramatic works. With respect to dramatic works, it might be argued that although one has attended a nonprofit performance he still might pay to see the work a second time; for example, when the cast was superior to that of the first performance. In the case of the motion picture, however, every performance is identical.

The argument in favor of the "for profit" limitation has centered around the public interest in certain civic, educational, and religious activities. ${ }^{46}$ Such an objective, however, could be realized easily through specific statutory language; this would preserve the rights of the copyright owner to the private or unauthorized performance of his motion picture.

\section{The "Public" Limitation}

All the performance rights which are granted under the Copyright Act are limited to those performances which are public.47 The "public"

43 NIMMER, Copyright \& 107.31 (1966).

$44 I d$. at 402 .

45 Ibid.

46 VARMER, op. cit. supra note 36, at 84 . Nimmer also suggests that "to prohibit unlicensed nonprofit performances of musical and nondramatic literary works in such public places as schools and churches would constitute an undue restriction on the benefits which should be available to the public." NIMMER, COPYRIGHT § 107.31, at 403 (1966).

47 Nimmer writes that "a performance in a private home with only members of the family and invited guests present clearly is not a 'public' performance." NIMMER, CoPYRIGHT $\S 107.21$, at 400 (1966). At the other extreme, a performance at which no restrictions were put on the number or class of people which attended would clearly be a "public" performance. No clear line falls between these two poles. In one case where a performance given at a club was attended only by members and invited guests, it was held that the performance was not public. Metro-Goldwyn-Mayer Distrib. Corp. v. Wyatt \& Maryland Yacht Club, 21 C.O. Bull. 203 (D.C. Md. 1932). However, cases were held to be public "where they occurred in clubs which catered primarily to their own members but did not place effective restrictions on attendance by uninvited members of the general public." NIMMER, Copyright $\S 107.21$, at 401 (1960), citing Lerner v. Club Wander In, Inc., 174 F. Supp. 731 (D.C. Mass. 1959); see M. Witmark \& Sons v. Tremont Social \& Athletic Club, 188 F. Supp. 787 (D.C. Mass. 1960). 
limitation is apparently based on the theory that "it would be, of course, unthinkable for an infringement to arise every time someone for the amusement of himself or his friends were to read a book aloud, or sing a song, or were to participate without an audience in an intimate play reading group." 48 In the case of motion pictures, however, it is not so apparent that the right to performances should be limited to those in public.

It is argued that due to the special nature of motion pictures, they should not be put in the same category as a dramatic performing right, particularly with respect to the "public performance" limitation. Motion pictures require broader protection than stage plays. ${ }^{49}$ The "pirating user of a copyrighted stage play takes only the directions in the form of the plot and dialogue, but makes his own production, requiring living actors for each infringing performance. No two performances are ever exactly identical, and nonpublic performance is not a serious injury." 50 The pirating user of a motion picture, however, appropriates not merely the plot and dialogue, but also "the best and only production containing the services of artists and actors otherwise unavailable, but can give unlimited identical performances in any place for any gathering, which compete with and destroy the value of the work for the copyright owner and his legitimate exhibition licensees." 11

Representatives of the motion picture industry have long urged an unlimited exhibition right, ${ }^{52}$ arguing that such a right is necessary "to assure control of the copyright owner over the exhibition of films in clubs, factories, camps, schools, and other such 'semipublic' places to which the general public is not invited ...."53 The evils against which the motion picture industry has reacted are well illustrated by the Maryland Yacht Club case. ${ }^{54}$ In that case, Judge Coleman followed the precedent of his opinion in the Tiffany case by holding that the performance of a motion picture photoplay at a social club, attended only by members and their guests, was not a public performance within the meaning of section $1(d)$ of the Copyright Act. In his opinion, Judge Coleman stated that he failed "to see that there is any substantial difference between the showing in the present case at the Maryland Yacht Club and a showing in a private home. We cannot measure the question

48 NIMMER, COPYRIGHT § 107.2 (1966).

49 VARMER, op. cit. supra note 36 , at 117 .

50 I SARgoy, StUdy of COPYright 225, as quoted in VARMER, op. cit. supra note 36 , at 111 .

51 Ibid.

52 VARMER, op. cit. supra note 36 , at 117 .

53 Ibid.

54 Metro-Goldwyn-Mayer Distrib. Corp. v. Wyatt \& Maryland Yacht Club, 21 C.O. Bull. 203 (D.C. Md. 1932). 
by numbers of persons. The public is not admitted to a social club of this kind as we understand the term 'public." "55

The assumption by both Congress and the courts has been that an important purpose of the copyright law is to permit the copyright owner to maximize his profits from the exploitation of his work. ${ }^{56}$ Because all the performances of a motion picture are identical, it is reasonable to assume that one who has attended a performance of a motion picture, whether that performance be "public" or "private," will normally not be willing to pay an admission fee to see the motion pictured performed a second time. It is clear, of course, that the right of the motion picture copyright owner to the performance of his work should not be unlimited. As noted above, ${ }^{57}$ an exception should be made in the case of performances given for civic, educational, and religious purposes. However, the rights of the motion picture copyright owner should extend to the private as well as to the public performance of his work. ${ }^{58}$ Distinguishing between public and private performances cannot be justified on policy grounds, for whether a performance be for profit or not, in public or in private, it will cause the copyright owner a financial loss by depriving him of a potential paying audience. ${ }^{59}$

$55 I d$. at 206.

56 The "authorization to grant to individual authors the limited monopoly of copyright is predicated upon the dual premises that the public benefits from the creative activities of authors, and that the copyright monopoly is a necessary condition to the full realization of such creative activities. Implicit in this rationale is the assumption that in the absence of such public benefit the grant of a copyright monopoly to individuals would be unjustified. This appears to be consonant with the pervading public policy against according private economic monopolies in the absence of overriding countervailing considerations." Nimmer, Copyright § 3(1) (1966). See also Mazer v. Stein, 347 U.S. 201 (1954).

57 See note 46 supra.

58 However, Sargoy points out that: "If the question of examination of a copyrighted film for private scholastic or research purposes were involved, so as to require its necessarily private projection for such purpose, I would think that this would more appropriately be left to the doctrine of 'fair use,' than to seriously affect the copyright product of an important copyright industry by an express limitation of exhibition rights to exhibitions given 'publicly,' 'in public,' or 'for profit' or even as ventured in the Varmer study, to exhibitions other than in a home for domestic entertainment." SARGOY FOR THE SUBCOMM. on Patents, Trademarks, and Copyrights, Senate Committee on the Judiciary, 86th Cong., 2d Sess., Comments and Views Submitted to the Copyright Office on Limitations on Performing Rights 135 (Comm. Print 1958).

59 Sargoy points out that "the motion-picture industry serves not only the 17,000 or so theaters which exhibit $35 \mathrm{~mm}$. prints commercially to the public, but a much greater number on non-theatrical outlets with $16 \mathrm{~mm}$. prints. There are not only hundreds of thousands of homes which have projection equipment, and license $16 \mathrm{~mm}$. prints from time to time from distributors in this field, but there are hundreds of thousands of private or semiprivate establishments, such as schools, colleges, clubs, children's camps, factories, and other places to which the general public would be denied access, which are potential exhibition licensees." VARMER, op. cit. supra note 36, at 117 n.146. 


\section{Economic Policy and Copyright Law}

\section{Protection Against Unauthorized Performances}

The justification for copyright is the inducement of artistic activity by offering economic return. Copyright will perform this function best if the rights given to the copyright owner are designed, so far as is compatible with competing social interests, to maximize the return from the copyrighted work. The value of motion pictures lies in their performance. The public will pay only to view what is projected on the screen, but will not pay "to inspect a copyrighted motion picture print in its container, or while it is being unwound from its spool."60 A motion picture copyright owner who has no protection against unauthorized performances of his movie does not, therefore, have effective protection.

The uniqueness of the motion picture industry in the copyright field is made apparent by its system of releasing a motion picture to the public through "distribution to thousands of exhibitors by bailment and rebailment of each of a few hundred copyrighted prints." 61 The most pressing problem for the motion picture industry at the moment lies in the authentic print which has escaped from the control of the copyright owner. Recent investigation indicates that thousands of feature and short subjects, particularly in sixteen millimeter, have gotten into the hands of bootleggers and are being rented throughout the United States, as well as internationally. ${ }^{62}$ These are not illegally duped prints, but prints belonging to, and put in circulation by, copyright owners. ${ }^{63}$ They are prints which were authentically made but which have been lost or stolen from licensees such as the Army and the Navy, the Veteran's Administration, the Red Cross, and others to whom they have been entrusted..$^{64}$ It is arguable that no copyright infringement is involved in such piracies, particularly where the rentor is careful to limit the use of the film to private exhibitions. ${ }^{65}$ But providing the copyright owner with a performance right would make the

60 Hearings Before Subcommittee No. 3 on the Study of the General Revision of the Copyright Law of the House Committee on the Judiciary, 89th Cong., 1st Sess., pt. 2, at 1003-04 (1965) (statement by Copyright Committee on the Motion Picture Association of America).

61 Register of Copyrights, for the House Committee on the Judiciary, 88th Cong., Ist. Sess., Discussion and Comments on Report of the Register of Copyrights on the General Revision of the U.S. Copyright Law 346 (Comm. Print 1963).

62 Id. at 23.

$63 \mathrm{Id}$. at 346.

64 Id. at 23.

65 Many of the distribution circulars state that these prints are for "home use" only. $I d$. at 347 . 
unauthorized use of his motion picture by such exhibitors a violation of the copyright law and would thereby provide the rightful owner with appropriate remedies. The copyright remedies of injunction, seizure, and destruction are necessary weapons in the armory of motion picture copyright owners if they are to protect themselves against such unauthorized exhibitions, and "are imperative to insure licensing systems and respect for licensing limitations." 66

\section{Pricing and the Necessary Rights to Maximize Profits}

Disk-television, as in the case of books and phonograph records, would probably be distributed through local shops. Moreover, the disks would most likely be rented rather than sold to the consumer because of the high capital cost required to produce a disk in relation to its relatively short period of use. Also, presumably, the consumer would not want to collect, and therefore purchase, the disks; they are unlike books-which people collect for reference and because of cultural traditions surrounding their ownership-and unlike phonograph recordswhich people are more likely to replay.

Motion picture copyright owners might sell their work directly to rental agencies at its market value. Such sales would be a fair and uncomplicated means of realizing a return on the copyright owner's investment. Economically, however, the copyright owner would better maximize his profits if he priced his work according to its use. In the case of motion pictures there is a clear relationship between the utility of the work to the consumer and its use, i.e., the number of performances he can enjoy. It would be difficult for the copyright owner to predict the use of his work within a stated interval since this would depend on the type of consumer involved. For example, the number of performances would be more unpredictable where the consumer used the motion picture for commercial purposes than in the case of private home showings. By pricing his work according to its use, rather than selling the motion picture at its market value, the copyright owner could more efficiently exploit the value of his work. ${ }^{67}$

66 Id. at 349 .

67 Under the present law, the leasing of disks through local shops would violate the Sherman Act, 26 Stat. 209 (1890), 15 U.S.C. $\$ 1-7$ (1964), where the leases were "used as an instrument for seeking market control ... in an attempt to monopolize." United States v. United Shoe Machinery Corp., 110 F. Supp. 295, 346 (D. Mass. 1953), aff'd per curiam, 347 U.S. 521 (1954). See also United States v. Paramount Pictures, 334 U.S. I31 (1947); Interstate Circuit v. United States, 306 U.S. 208 (1939). Those who presently display motion picture films prefer to rent rather than buy because they only want the films for a short period of time. In the case of disk-television, however, rental stores would need the disks for a longer time, perhaps over their effective lives. Under the Sherman Act this would be treated like any other retailing situation where a firm is not permitted to keep 
If Congress wishes to increase the protection given to a motion picture copyright owner, it has two alternatives. It may expand the definition of copy under the statute to include all forms of motion pictures, and permit the copyright owner to exploit his work by selling to rental agencies. However, if Congress adopts the traditional assumption that a primary purpose behind the copyright system is to permit the copyright owner to maximize his profits from his work, it should choose the second alternative of extending the rights of the motion picture copyright owner to the performance of his work which would allow him to discriminate in the price of his work according to its use. ${ }^{68}$

control of conditions of resale by retaining "title" to the goods. See Simpson v. Union Oil Co., 377 U.S. 13 (1963). This would force the motion picture owner to sell the disks to the local shops. Under the first sale doctrine, the original owner would loose any right to the performance of the disks. In Bobbs-Merrill Co. v. Strauss, 210 U.S. 339, 350 (1907), the Court stated: "In our view the copyright statutes, while protecting the owner of the copyright in his right to multiply and sell his production, do not create the right to impose, by notice . . a limitation at which the book shall be sold at retail by future purchasers, with whom there is no privity of contract."

68 Price discrimination is not always antithetical to the public interest and may in many instances be promotive of that interest. Samuelson, Foundations of Economic ANalysis $42-45$ (1947).

Arguments which give special treatment to the motion picture copyright owner, as opposed to an author or a composer, can be justified because the performance of a motion picture is distinguishable from the reading or lending of a book, and the performance of a phonograph record. Economically, motion pictures have been marketed most successfully, and therefore almost exclusively, through leasing arrangements. The business of lending books, however, does not operate on a large or successful scale. Thus, the establishment of a copyright owner's right to the lending of his book, and with it the establishment of an additional fee, would "probably tend to drive lending libraries out of business. In the long run this would result in less net income for both publisher and author." REGISTER of Copyrights, For the House Committee on the Judiciary, 88 th Cong., 2D Sess., Preliminary Draft for Revised U.S. Copyright Law and Discussions and Comments on the Draft 192 (Comm. Print 1964).

The difference between books and motion pictures is in large part a result of the strong cultural tradition surrounding the ownership of books. People who can afford it buy books because they want to own them, even though they seldom open them again after once reading them. There is no such tradition surrounding motion pictures. In the case of books this means that publishers can make a profit selling books, even against the competition of free loan libraries. Thus, in contrast to the performance of a motion picture, the lending of a book does not result in a significant decrease in the amount of consumers willing to pay for the author's work.

Phonograph records are sold directly to the consumer. This is in direct contrast to motion pictures which are distributed almost exclusively through leasing arrangements. The reason for the difference in the marketing of motion pictures and records is that one performance of a motion picture generally exhausts the market for those who see it. Records, on the other hand, are played over and over. A record lent to a friend may encourage him to buy it himself. Record companies encourage exposure of their records on radio broadcasts because it helps to increase their sales and therefore their profits. Thus, as in the case of books and unlike the case of motion pictures, the phonograph record copyright owner makes his profits from the sale, and not from the leasing, of his work. Therefore, 


\section{The Proposed Bill}

Under the proposed bill for the general revision of the copyright law, ${ }^{69}$ the definition of a motion picture is made in general terms, and would include disk-television. Section 101 states:

"Motion pictures" are audiovisual works consisting of a series of related images which, when shown in succession, impart an impression of motion, together with accompanying sounds, if any. ${ }^{70}$

"Audiovisual works" are defined as:

works that consist of a series of related images which are intrinsically intended to be shown by the use of machines or devices such as projectors, viewers, or electronic equipment, together with any accompanying sounds, if any, regardless of the nature of the material objects, such as films or tapes, in which the works are embodied. ${ }^{71}$

The bill would appear to protect the rights of a motion picture copyright owner. Pursuant to section 106(1), the owner of a copyright is given the exclusive right to reproduce, or authorize the reproduction of, the copyrighted work in "copies." The definition of "copies" is broad and apparently includes any device by which motion pictures may be performed, including disk-television:

Material objects, other than phonorecords, in which a work is fixed by any method now known or later developed, and from which the work can be perceived, reproduced, or otherwise communicated, either directly or with the aid of a machine or device. The term "copies" includes the material object, other than a phonorecord, in which the work is first fixed. ${ }^{72}$

Thus, the unauthorized manufacture of motion picture films, videotapes, disks, or other "material objects" is an infringement under the proposed bill.

the right to the reproduction and sale of his records, and not to their performance, may be all that is necessary for the copyright owner to maximize his profits from the exploitation of his work.

69 H.R. 2512, 90th Cong., 1st Sess. (1967).

$70 \mathrm{Id}$. $\mathrm{101.}$.

71 Ibid. The examples given in the phrase "such as films or tapes" do not add much to the definition of audiovisual works. They are limited in scope and would not include, for example, used in disk-television, and therefore might possibly serve to limit the definition of audiovisual works to only those works embodied in "films or tapes." Thus, it would appear wiser to delete the phrase entirely.

72 Id. § 101. 
But perhaps the most dramatic change in copyright law which is made under the proposed bill is the explicit recognition of a motion picture copyright owner's exclusive right to the public performance of his work. Section 106 of the proposed bill provides:

[T] he owner of copyright . . . has the exclusive rights to do and to authorize any of the following:

(4) in the case of ... motion pictures and other audiovisual works, to perform the copyrighted work publicly. ${ }^{73}$

The proposed bill thus properly distinguishes between the right to "copy" and the right to "perform" motion pictures, thereby avoiding both the possibility of stretching the definition of "copy" to include "performance" as was done in the Patterson case, ${ }^{74}$ and the artificial distinction made, if only by implication, in the Mura case..$^{75}$

The right to the performance of motion pictures under section 106(4) is, however, limited to those performances which are made in public. ${ }^{76}$ This solution gives both too much and too little protection to the copyright owner. It gives too much in the sense that no performance right, public or private, should be given if Congress decides that the right of the motion picture copyright owner to sell his work on the open market is a sufficient protection for his investment. It gives too little in the sense that if Congress wishes to provide a right to performance, it should extend the right to all performances to permit the motion picture copyright owner to price according to the use of his work in the case of a private or home performance as well as in the case where the work is performed publicly. ${ }^{77}$

\footnotetext{
$73 I d . \S 106(4)$.

74 See note 30 supra.

75 See note 32 supra.

78 "To perform or display a work 'publicly' means:

(I) to perform or display it at a place open to the public or at any place where a substantial number of persons outside of a normal circle of a family and its social acquaintances is gathered;

(2) to transmit or otherwise communicate a performance or display of the work to the public by means of any device or process, whether the members of the public capable of receiving the performance or display receive it in the same place or in separate places and at the same time or at different times."
}

H.R. 2512, 90th Cong., 1st Sess. § 101 (1967).

77 The unlimited right to the performance of motion pictures raises the possibility that "vast numbers of innocent home viewers will find themselves liable for copyright infringement." Niamer, Copyright $\$ 109.4$, at 438 (1966). Thus, where there are unlimited rights to the performance of motion pictures, an exception should be made which would deny recovery by the copyright owner against an innocent, private, nonprofit performance. The home viewer should be liable for copyright infringement only where he had reason to know, through notice on the disk or the suspicious circumstances under which he acquired the disk, that his performance was an infringement. Where a home viewer has reason to 
The proposed bill does, however, somewhat limit the exclusive rights given to the motion picture copyright owner. A new provision states that "the fair use of a copyrighted work . . . is not an infringement of copyright." "78 The copyright owner's right to the performance of his motion picture is further limited where the performance is for certain educational, ${ }^{79}$ religious, ${ }^{80}$ or charitable ${ }^{81}$ purposes.

Finally, the proposal gives the motion picture copyright owner sufficient power to enforce his rights to the performance of his work. The meaning of "copy" is defined in sufficiently broad terms to include the disks used in disk-television, and other motion picture devices which may be invented in the future, thus giving an expanded right of the copyright owner to "reproduce the copyright work in copies" under section 106(1). The copyright owner is also given extensive rights to the distribution of his work. Section 106(3) gives him the right "to distribute copies or phonorecords of the copyrighted work to the public by sale or other transfer of ownership or by rental, lease, or lending." 82 This would seem to be a proper and beneficial extension of the limited right to "vend" provided by section 1(a) of the present Copyright Act.83

\section{Conclusion}

Because disk-television would normally be performed in private and not for profit, it is a good example of why both the present Copyright Act and the proposed bill are inadequate to meet the copyright prob-

know that his performance is an infringement, he should be subject to all the available copyright remedies. The problem of the innocent, private, nonprofit infringer does not come up under the proposed bill, since the rights to performance provided therein are limited to those performances made in public. See H.R. 2512. 90th Cong., Ist Sess. §§ 106(4), (5) (1967).

78 "Notwithstanding the provisions of section 106, the fair use of a copyrighted work, including such use by reproduction in copies or phonorecords or by any other means specified by that section, for purposes such as criticism, comment, news reporting, teaching, scholarship, or research, is not an infringement of copyright. In determining whether the use made of a work in any particular case is a fair use, the factors to be considered shall include: (1) the purpose and character of the use; (2) the nature of the copyrighted work; (3) the amount and substantiality of the portion used in relation to the copyrighted work as a whole; and (4) the effect of the use upon the potential market for or value of the copyrighted work." Id. at $\S 107$.

For a general discussion of the doctrine of fair use, see NIMMER, CopYright $\S 145$ (1966).

79 Id. $\$ \S 110(1),(2),(4)$.

$80 I d$. \& $110(3)$, (4).

81 Id. § 110(4), $111(2) 2$.

82 Id. \& $106(3)$.

83 Section 106(3) appears to codify the right of a copyright owner to lease his work, recognized in United States v. United Shoe Machinery Corp., 110 F. Supp. 295 (D. Mass. 1953), aff'd per curiam, 347 U.S. 521 (1954). However, it is possible that the explicit statutory grant of a leasing right could also be interpreted as an exception to the Sherman Act. See note 67 supra. 
lems caused by the advancing technology in the production of motion pictures. Under the former, the development of disk-television could lead to a large scale appropriation of motion picture films since neither the manufacture nor the performance of disk-television would be held to be a "copy" of a motion picture film within the meaning of section I(a). Under the latter, although Congress appears to support the extension of the right of the copyright owner to the performance of his work, the right is limited to those performances given publicly.

Disk-television has not yet been perfected. There may still be technological and economic problems to solve before it is successfully marketed. ${ }^{84}$ However, whether or not disk-television is finally a success, the inadequacies of the Copyright Act and the proposed revision will continue to exist. The success of "free" television has suggested that there is a large demand for "home viewing." And as the technological and economic problems are solved, and new devices ${ }^{85}$ are produced to satisfy the "home viewer" market, it will become more important to provide the motion picture copyright owner with broader rights to the performance of his work, thereby permitting him to commercially exploit and receive the economic benefits of a growing "home viewer" market.

\footnotetext{
84 Wall Street Journal, March 1, 1966, p. 31, col. 3.

85 R.C.A. has recently announced that it is presently developing a home color television tape recorder player which "would not only record programs off the air, but also would permit consumers to buy or rent color video tapes of other special program material, just as they buy original cast albums and other musical recordings . . . . Coupled with a small television camera, it would enable the user to make his home video tape recordings to play back on the T.V. set . . . "Wall Street Journal, May 4, 1966, p. 6, col. 2.
} 